\title{
Torbangun (Coleus amboinicus Lour) Extracts Affect Microbial and Fungus Activities
}

\author{
Muhammad Muzaffar Ali Khan Khattak ${ }^{1 *}$, Muhammad Taher ${ }^{2}$, Rizal Damanik ${ }^{3}$, Suzanah \\ Abdulrahman $^{4}$, Ibrahim Abu Bakar ${ }^{1}$ and Azhary Yahaya ${ }^{1}$
}

${ }^{1}$ Nutrition Sciences, Kulliyyah of Allied Health Sciences, International Islamic University, Kuantan 25200, Pahang, Malaysia

${ }^{2}$ Pharmaceutical Technology, Kulliyyah of Pharmacy, International Islamic University, Kuantan 25200, Pahang, Malaysia

${ }^{3}$ Department of Community Nutrition, Faculty of Human Ecology, Bogor Agricultural University, Bogor 16680, Indonesia

${ }^{4}$ Biomedical Sciences, Kulliyyah of Allied Health Sciences, International Islamic University, Kuantan 25200, Pahang, Malaysia

\begin{abstract}
Coleus also known as Torbangun or Ati Ati plants leaves i.e. Coleus amboinicus Lour from Indonesia (CAL-I) and Coleus aromaticus (CAT-M), Pogostemon cablin (PC-M), Coleus blumei-red leaves (CBR-M), Coleus amboinicus(CAL-M) Coleus blumei -purple leaves (CBP-M) from Malaysia were collected, freeze dried and extracted with aqueous methanol. The effect of the extract was assessed on microbial and fungal activities in relation to their phytochemicals and antioxidants concentrations. The total phenolic content was determined according to the Folin-Ciocalteu method whilst antioxidant activity was assessed using 2, 2-diphenyl-1-picrylhydrazyl (DPPH) method. The anti-microbial and anti-fungal activities were assessed by minimum inhibitory concentrations (MIC) and disc diffusion methods. The result indicates that the extracts are rich sources of phytochemicals and antioxidants from the listed plants. When the effect of the extracts was assessed on microbial and fungal activities it was observed that the effect was more pronounced on the gram-positive bacteria compared to gram-negative bacteria. Furthermore, there was strong association between phytochemicals and antioxidants concentration and with the microbial and fungal activities. However, it was not consistent for all types of strains. This study shows that Torbangun plants extracts are rich in phenolic contents therefore; it can be used as free radical scavengers and antimicrobial agent apart from other traditional uses.
\end{abstract}

Keywords: Torbangun, coleus, phytochemical, antimicrobial, antifungal.

\section{INTRODUCTION}

There is continued search for medicinal plants or herbs around the world to make better use of the resources available without putting ourselves to the synthetic drugs therapy. Studies have been conducted in different parts of the world to understand the properties, safety and efficacy of natural sources. According to World Health Organization, medicinal plants would be the best source to obtain a variety of natural therapies [1]. Around the globe the demand for traditional medicine is increasing due to natural ingredients. Plants components, for example, phenolic compounds in plants are important for human health [2]. Similarly, antioxidants play an important role in human health including prevention of oxidative damages and reduce risks of chronic disease [3-6]. The balance between an individual's intake of antioxidants and exposure to free radicals is considered crucial for health [7]. In numbers there are

*Address correspondence to this author at the Nutrition Sciences, Kulliyyah of Allied Health Sciences, International Islamic University, Kuantan 25200, Pahang, Malaysia; Tel: +60-9-570-5305; Fax: +60-9-570-5440;

E-mail:mkbiol@yahoo.com numerous phenolic compounds, flavonoid possessing antioxidant activity [8,9]. Recent studies on tea provided evidence that green tea contains catechins which is an anti oxidative property and have effect on angiogenesis, [10]. The use of plants and herbs as antioxidants in processed foods is becoming of increasing interest in the food industry as an alternative to synthetic antioxidants [11-13]. The use of plants compounds for pharmaceutical purposes has been also gradually increasing. Therefore, such plants are considered important to be investigated for their properties, safety and efficacy. Plants products have been used as antimicrobial traits, which are because of the active components synthesized in plants [14]. Plants from Lamiaceae family have been shown to possess antimicrobial activity. Plant from this family, such as Coleus forkohlii, C. amboinicus, C. aromaticus, $C$. blumei and others possibly have anti-microbial activity. The leaves of these plants are traditionally used for treatment of severe bronchitis, asthma, diarrhea, epilepsy, renal calculi and fever. The Coleus species are used in the Asian traditional medicines to treat various disease conditions. These studies have reported that concentration of phenolic components/ 
contents is fairly higher [15]. Therefore capacity to act as an antioxidants and antimicrobial agents is presumably also higher. Therefore, this study was designed to assess the association between the concentrations of phytochemicals and antioxidants and microbial and fungal activities.

\section{METHOD}

As mentioned earlier, that this study involved six plants from Lamiaceae family. The leaves of Coleus amboinicus (CAL-I) from Jakarta (Indonesia) and Coleus_aromaticus (CAT-M), Pogostemon cablin (PC$\mathrm{M})$, Coleus blumei -red leaves (CBR-M), Coleus amboinicus- (CAL-M) Coleus blumei -purple leaves (CBP-M) from Kuantan (Malaysia) were acquired through local supplier and propagated at kitchen garden. The plants are enlisted in the Table $\mathbf{1}$ and the abbreviations assigned here to the plants have been used in rest of the article instead of the full name.

Fresh leaves were cleaned and rinsed with distilled water to remove all contaminates (dirt and soil). The leaves were rinsed and freeze-dried using a freeze dryer (Biotron Cleanvac 12). The freeze dried leaves were ground, sieved to $0.45 \mu \mathrm{m}$ using Micro-mill (BelArt Products, Voigt Global Distribution Inc P.O. Box 1130, Lawrence, KS 66044-8130, United States of America) and stored for further analysis. The ground sample (500 mg) was extracted by suspension in $50 \mathrm{ml}$ of (40: 60) aqueous methanol (v/v). The aqueous methanol containing sample was heated and shake at $60{ }^{\circ} \mathrm{C}$ for 24 hours. The extracts were filtered through fast filter paper (Whatman No 3, Whatman International Limited) into $100 \mathrm{ml}$ volumetric flask, rinsed with aqueous methanol and the volume was made up to $100 \mathrm{ml}$. Total phenolic contents were determined by the Folin-Ciocalteau method [16], based on complex formation of molybdenum-tungsten blue. The samples were allowed to react with Folin-Ciocalteu's reagent and sodium carbonate solution. The phenolic contents were estimated using a standard curve of gallic acid and expressed as $\mathrm{mg}$ of gallic acid equivalents (GAE) /g dried weight of sample (DW). The total flavonoid content of the plant extract was estimated according by Aluminum chloride method as described by Quercetin was used as reference compound to produce the standard curve and expressed as $\mathrm{mg}$ of Quercetin Equivalents (QE)/100 mg of plant extract. The antioxidant concentration was assessed by radical scavenging activity of extracts by the modified method of Brand-Williams, et al., [17]. This method involves the utilization of the stable 2, 2-diphenyl-1-picrylhydrazyl (DPPH) radical. When the odd electron of DPPH radical makes pair with hydrogen from a free radical scavenging antioxidant and reduced to $\mathrm{DPPH}-\mathrm{H}$, the colour turns from purple to yellow. The resulting discolorization is stoichiometric with respect to number of electrons captured.

\section{Type of Microorganism}

The methanolic extracts of the leaves were tested for their antimicrobial activity for the following microorganisms:

1. Gram Positive bacteria:
a. Bacillus subtilis
b. Staphylococcus aureus

2. Gram Negative bacteria:
a. Escherichia coli
b. Pseudomonas aruginosa

3. Fungi:

a. Candida albicans

Table 1: Location and Types of the Plants Extracts

\begin{tabular}{|c|c|c|c|}
\hline Scientific name & & Common name & Place of collection \\
\hline \hline Coleus amboinicus & CAL-I* & Torbangun & Jakarta \\
\hline Coleus aromaticus & CAT-M** Kuantan & Jemuju, Bangun-bangun \\
\hline Pogostemon cablin & PC-M & Nilam & Kuantan \\
\hline Coleus blumei - purple leaves & CBR-M & Ati-ati & Kuantan \\
\hline Coleus blumei - red leaves & CAL-M & Ati-ati merah & Kuantan \\
\hline Coleus amboinicus & CBP-M & Bangun-bangun & \\
\hline
\end{tabular}

"Indonesia, " Malaysia. 
These microorganisms were obtained from the culture collection at the Biotechnology Laboratory, Kulliyyah of Science, International Islamic University Malaysia (IIUM), Kuantan.

\section{Antimicrobial Activity of the Plant Extract}

\section{Minimum Inhibitory Concentrations (MIC) Method}

The MIC method using broth dilution method was applied on extracts that proved their high efficacy against test microorganisms by disc diffusion methods. The standard agar dilution protocol with doubling dilution was used. The extract was incorporated into nutrient broth at concentrations of $0.5-2.5 \mathrm{mg} / \mathrm{ml}$. A control without the extract was also set up. $10 \mu \mathrm{l}$ each of the test organisms, previously diluted to give $10^{6}$ $\mathrm{CFU} / \mathrm{ml}$ was used to inoculate the plates. These were incubated at $37^{\circ} \mathrm{C}$ for 24 hours in the first instance, and for another 24 hours, before the results were recorded after observing for growth. The minimum inhibitory concentrations (MICs) of the extract for each test microorganism were regarded as the agar plate with the lowest concentrations without growth $[18,19]$.

\section{Disc Diffusion Technique}

The microorganisms were maintained on stock culture agar inoculated in nutrient broth. The broth seeds were inoculated at $37^{\circ} \mathrm{C}$ for 24 hours. The antibacterial assay was carried out by disc diffusion technique. Disc was impregnated with extracts, dried and then placed on the inoculated agar. The clear zone of inhibition around the disc was measured in millimeters (Table 2).

\section{Preparation of Disc}

Dried ground leaves were weighed, macerated with $60 \%$ methanol for 24 hours at $60^{\circ} \mathrm{C}$ and then filtered. The filtrate was evaporated to a thick filtrate at $60^{\circ} \mathrm{C}$ then the extracts were reconstituted with $60 \%$ methanol. The concentration brought to be equivalent to $100 \mathrm{mg}$ of dried leaves extracts / $\mathrm{ml}$. The discs (diameter, $6 \mathrm{~mm}$ ) were impregnated with $20 \mu \mathrm{l}$ of extract, corresponding to $2 \mathrm{mg}$ of dried leaves per discs and allowed to dry under laminar flow cabinet. Disks impregnated with 20 ul of aqueous methanol and sterilized water served as negative controls.

\section{Procedures}

Screening of leaf extracts for antimicrobial activity was performed by the disk diffusion method. It was performed using an $18 \mathrm{~h}$ culture (approximately $10^{5} \mathrm{CFU} / \mathrm{ml}$ at $37^{\circ} \mathrm{C}$ in $10 \mathrm{ml}$ of Mueller Hinton Broth). Five hundred micro-liters of the suspensions were

\section{Table 2: Classification for Zone Diameter Interpretive with Standards (Chloramphenicol)}

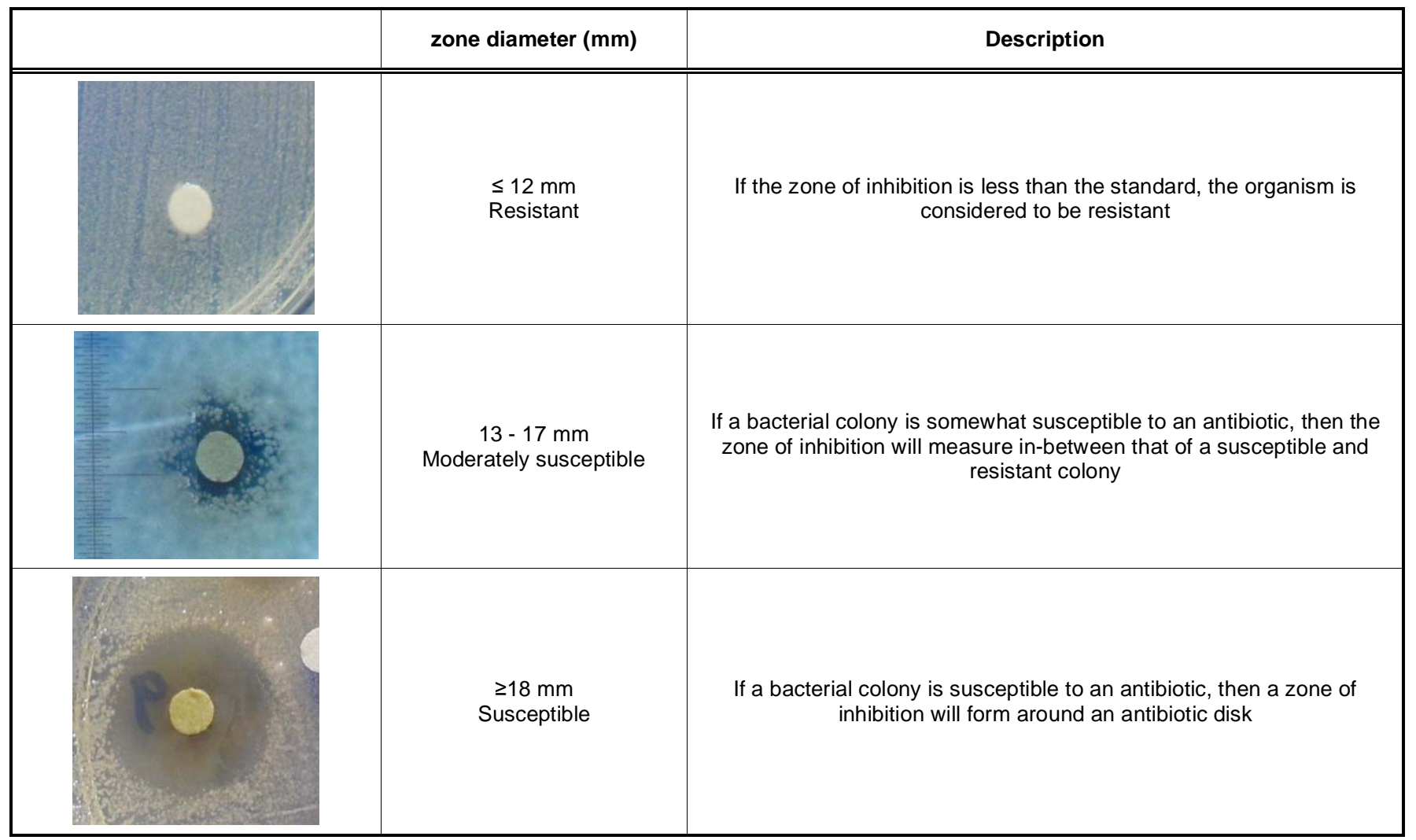


spread over the plates containing Mueller-Hinton agar using a sterile cotton swab in order to get a uniform microbial growth on both control and test plates. The discs (contained crude extract) placed on the inoculated agar. A standard disc contained chloramphenicol $(25 \mu \mathrm{g} / \mathrm{disc})$ was used as positive reference control whereas blank disc was used as negative controls. All petridishes were sealed with sterile parafilm to avoid eventual evaporation of the samples. The plates were left for $30 \mathrm{~min}$ at room temperature to allow the diffusion of extract, and then incubated at $37^{\circ} \mathrm{C}$ for $24 \mathrm{~h}(18 \mathrm{~h}$ was fixed as the maximum since there was no change in the inhibition up to $24 \mathrm{~h}$ for bacteria whereas the incubation of $30^{\circ} \mathrm{C}$ for 24-48 $\mathrm{h}$ was used for yeast and fungi. The results were recorded by measuring the zones of growth inhibition surrounding the disc. Clear inhibition zones around the discs indicated the presence of antimicrobial activity. The antibacterial activity was interpreted from the size of the diameter from the clear zones surrounding the discs. After incubation, the diameter of inhibition zone was measured in millimeters. An inhibition zone of $14 \mathrm{~mm}$ or greater (including diameter of the disc) was considered as high antibacterial activity. Diameter of inhibition zones were measured manually in triplicate [17, 18, 20, 21]. Data were reported as mean and standard deviation for triplicate measurements. Analysis of variance and Tukey's honestly significant difference tests were conducted using SPSS software for Windows (Version 12.0) SPSS Inc., Chicago) to determine differences among means and the statistical significance was determined at $95 \%$ confidence interval.

\section{RESULTS AND DISCUSSION}

The present study revealed some interesting findings for the Torbangun plants grown in this part of the world. The biological activity in vitro, especially in relation to total phenolic, flavonoid and antioxidants contents and antimicrobial activities were evaluated for the extracts of aforementioned plants of coleus species. As reported previously elsewhere that in Bataknese traditional cuisine, Torbangun is used for the induction of lactation soon after giving birth [22-25]. The use at the time of birth might have clinical importance due to its observed contents of phytochemicals and antioxidants [26]. The results on the microbial activity in relation to the treatment with extracts are shown in the Tables 3-5. From data collected in this study, it is interpreted as the lowest is the MIC, the highest is antimicrobial activity whereas when MIC is higher than $25 \mathrm{mg} / \mathrm{ml}$ is considered inactive [27]. From the Table $\mathbf{3}$ it is evident that all plant extracts showed minimum inhibitory concentration (MIC) and ranged from $1.0-2.0 \mathrm{mg} / \mathrm{ml}$ inhibiting the growth of S. aureus, E. coli, $P$. aeruginosa and $B$. subtilis. All the plant extracts do not inhibit the growth of $C$. albicans at a concentration range of 0.5-2.5 $\mathrm{mg} / \mathrm{ml}$. The MIC values indicate that extracts were more potent against bacteria than against fungi. The extract from CAL-I showed the lowest MIC $(1.0 \mathrm{mg} / \mathrm{ml})$ compared with other extracts. On overall antimicrobial activity is indicative of the potential of the extract as effective medicaments in the treatment of microbial infection. The results indicate that the growth of Pseudomonas aeruginosa, Escherichia coli, Bacillus subtilis and Staphylococcus aureus were inhibited as well with exception of Candida albicans. The size of the zone inhibition was compared with the standardized zones of inhibition by antibiotic (Table 5). The antimicrobial activity of extract of CAT-M, PC-M, CBP$M$, CBR-M and CAL-M is indicated in the Table 4. There was a significant $(p<0.05)$ difference among the zone inhibition of five microorganisms exposed to a concentration of $2 \mathrm{mg} / \mathrm{disc}$ of the extracts. Size of zone inhibition of Staphylococcus aureus (17.8-21.6 mm) was significantly $(p<0.05)$ larger than for the other four microorganism Bacillus subtilis (7.3-9.5mm), Pseudomonas aeruginosa (6.5-8.8.0mm), Escherichia coli $(7.3-9.3 \mathrm{~mm})$ and Candida albicans. Result also shows that CAT-M, PC-M, CBP-M, CBR-M and CAL-M extracts are more effective in inhibiting Staphylococcus aureus compared to other bacteria Pseudomonas aeruginosa, Bacillus subtilis. The effect was more pronounced on gram positive bacteria compared to gram negative bacteria. However, there was no effect on the growth of fungus. This result shows that the total amount phenol content is not the only factor that can affect the growth of microorganisms as observed in case of CAL-I. Despite of lower concentration it is more effective to inhibit the growth of three bacterial strains (Pseudomonas aruginosa, Escherichia coli and Bacillus subtillis (Table 5). The current observations is providing one bit of puzzle that plants components for example, phytochemicals and antioxidants processed foods prevent bacterial activities [11-13]. Similarly, it can be further exploited for pharmaceutical industries as antimicrobial products [14]. In previous studies such plants have been shown to possess antimicrobial activity and this family, such as Coleus forskohlii, $C$. amboinicus, $C$. aromaticus, and $C$. blumei and have been used traditionally in the treatment of certain disease situations [15]. 
Table 3: Minimum Inhibitory Concentration (MIC) Values of the $60 \%$ Methanol Leaf Extracts

\begin{tabular}{|c|c|c|c|c|c|c|}
\hline \multirow{3}{*}{$\begin{array}{c}\text { Plant leaves } \\
\text { Extracts }\end{array}$} & \multirow{3}{*}{ Conc. $\mathrm{mg} / \mathrm{ml}$} & \multicolumn{5}{|c|}{ Presence/Absence of Growth } \\
\hline & & \multicolumn{4}{|c|}{ Bacteria strain } & \multirow{2}{*}{$\begin{array}{c}\text { Fungus } \\
\mathrm{Ca}\end{array}$} \\
\hline & & $\mathbf{P a}$ & Ec & $\mathrm{Sa}$ & Bs & \\
\hline \multirow{5}{*}{ Coleus amboinicus - Indonesia (CALI) } & 2.5 & - & - & - & - & + \\
\hline & 2.0 & - & - & - & - & + \\
\hline & 1.5 & - & - & - & - & + \\
\hline & 1.0 & - & - & - & - & + \\
\hline & 0.5 & + & + & + & + & + \\
\hline \multirow{5}{*}{ Coleus aromaticus (CATM) } & 2.5 & - & - & - & - & - \\
\hline & 2.0 & - & - & - & - & - \\
\hline & 1.5 & + & + & + & + & + \\
\hline & 1.0 & + & + & + & + & + \\
\hline & 0.5 & + & + & + & + & + \\
\hline \multirow{5}{*}{ Pogostemon cablin (PCM) } & 2.5 & - & - & - & - & + \\
\hline & 2.0 & - & - & - & - & + \\
\hline & 1.5 & + & + & + & + & + \\
\hline & 1.0 & + & + & + & + & + \\
\hline & 0.5 & + & + & + & + & + \\
\hline \multirow{5}{*}{ Coleus blumei -purple leaves (CBPM) } & 2.5 & - & - & - & - & + \\
\hline & 2.0 & - & - & - & - & + \\
\hline & 1.5 & + & + & + & + & + \\
\hline & 1.0 & + & + & + & + & + \\
\hline & 0.5 & + & + & + & + & + \\
\hline \multirow{5}{*}{ Coleus blumei -red leaves (CBRM) } & 2.5 & - & - & - & - & + \\
\hline & 2.0 & - & - & - & - & + \\
\hline & 1.5 & + & + & + & + & + \\
\hline & 1.0 & + & + & + & + & + \\
\hline & 0.5 & + & + & + & + & + \\
\hline \multirow{5}{*}{ Coleus amboinicus - Malaysia (CALM) } & 2.5 & - & - & - & - & + \\
\hline & 2.0 & - & - & - & - & + \\
\hline & 1.5 & + & + & + & + & + \\
\hline & 1.0 & + & + & + & + & + \\
\hline & 0.5 & + & + & + & + & + \\
\hline
\end{tabular}

$(+)=$ presence of growth, $(-)=$ absence of growth, $\mathrm{Sa}=\mathrm{S}$. aureus, $\mathrm{Ec}=E$. coli, $\mathrm{Pa}=P$. aeruginosa, $\mathrm{Bs}=\mathrm{B}$. subtilis, $\mathrm{Ca}=C$. albicans.

Table 4: Antibacterial Activity of Extracts Against Microorganism Using Disc Diffusion Method

\begin{tabular}{|c|c|c|c|c|c|}
\hline \multirow{3}{*}{$\begin{array}{l}\text { Plant Extracts } \\
\text { (2mg/disc) }\end{array}$} & \multicolumn{5}{|c|}{ Zone of Inhibition (mm) } \\
\hline & \multicolumn{2}{|c|}{ Gram negative bacteria } & \multicolumn{2}{|c|}{ Gram positive bacteria } & \multirow{2}{*}{$\begin{array}{c}\text { Fungi } \\
\mathrm{Ca}\end{array}$} \\
\hline & $\mathrm{Pa}$ & Ec & Sa & Bs & \\
\hline CALI & $18.5 \pm 0.3^{a}$ & $16.6 \pm 1.5^{\mathrm{a}}$ & $\mathrm{Na}$ & $13.0 \pm 0.8^{\mathrm{a}}$ & $\mathrm{N}$ \\
\hline CATM & $7.3 \pm 0.5^{c}$ & $7.3 \pm 0.5^{\mathrm{bc}}$ & $19.3 \pm 0.5^{\mathrm{ab}}$ & $7.5 \pm 0.0^{c}$ & $\mathrm{~N}$ \\
\hline PCM & $10.0 \pm 1.3^{b}$ & $8.3 \pm 1.5^{\mathrm{bc}}$ & $21.6 \pm 1.5^{\mathrm{a}}$ & $8.8 \pm 0.2^{b c}$ & $\mathrm{~N}$ \\
\hline CBPM & $7.5 \pm 0.8^{c}$ & $9.3 \pm 0.5^{b}$ & $19.8 \pm 1.7^{\mathrm{ab}}$ & $8.1 \pm 0.2^{b c}$ & $\mathrm{~N}$ \\
\hline CBRM & $6.5 \pm 0.0^{c}$ & $6.6 \pm 0.2^{c}$ & $17.8 \pm 0.2^{b}$ & $7.5 \pm 1.7^{c}$ & $\mathrm{~N}$ \\
\hline CALM & $9.6 \pm 1.0^{\mathrm{bc}}$ & $7.3 \pm 0.5^{\mathrm{bc}}$ & $19.8 \pm 0.2^{\mathrm{ab}}$ & $8.1 \pm 1.1^{b c}$ & $\mathrm{~N}$ \\
\hline
\end{tabular}

$\mathrm{Sa}=\mathrm{S}$. aureus, $\mathrm{Ec}=E$. coli, $\mathrm{Pa}=P$. aeruginosa, $\mathrm{Bs}=\mathrm{B}$. subtilis, $\mathrm{Ca}=C$. albicans, Data are mean \pm standard deviation, $\mathrm{n}=3 ; \mathrm{N}=\mathrm{no}$ activity . 
Table 5: Phytochemicals and Antioxidants Activity $\left(\mathrm{IC}_{50}\right)$ and Microbial Activity of Extracts

\begin{tabular}{|c|c|c|c|c|c|c|c|c|}
\hline \multirow{2}{*}{$\begin{array}{c}\text { Plant } \\
\text { Extracts }\end{array}$} & \multirow{2}{*}{ Phenol content } & \multirow{2}{*}{$\begin{array}{c}\text { Flavonoid } \\
\text { content }\end{array}$} & \multirow{2}{*}{$\begin{array}{l}\text { Antioxidant } \\
\text { activity }\end{array}$} & \multicolumn{5}{|c|}{$\begin{array}{c}\text { Antimicrobial activity } \\
\text { [Zone of Inhibition }(\mathrm{mm})]\end{array}$} \\
\hline & & & & \multicolumn{2}{|c|}{ Gram -ve bacteria } & \multicolumn{2}{|c|}{ Gram +ve bacteria } & $\begin{array}{c}\text { Fungi } \\
\mathrm{Ca}\end{array}$ \\
\hline CALI & $55.21 \pm 3.20^{d}$ & $0.178 \pm .07^{\mathrm{e}}$ & $34.1 \pm 1.8^{\mathrm{e}}$ & $18.5 \pm 0.3^{\mathrm{a}}$ & $16.6 \pm 1.5^{\mathrm{a}}$ & na & $13.0 \pm 0.8^{\mathrm{a}}$ & $\mathrm{N}$ \\
\hline CATM & $90.41 \pm 1.95^{b}$ & $6.00 \pm 0.24^{d}$ & $14.5 \pm 0.08^{c d}$ & $7.3 \pm 0.5^{c}$ & $7.3 \pm 0.5^{\mathrm{bc}}$ & $19.3 \pm 0.5^{\mathrm{ab}}$ & $7.5 \pm 0.0^{c}$ & $\mathrm{~N}$ \\
\hline CBPM & $94.01 \pm 4.61^{\mathrm{a}}$ & $15.21 \pm 0.28^{a}$ & $12.9 \pm 0.26^{b c}$ & $7.5 \pm 0.8^{c}$ & $9.3 \pm 0.5^{b}$ & $19.8 \pm 1.7^{\mathrm{ab}}$ & $8.1 \pm 0.2^{b c}$ & $\mathrm{~N}$ \\
\hline CBRM & $85.35 \pm 3.90^{c}$ & $13.66 \pm 0.18^{b}$ & $15.9 \pm 0.21^{d}$ & $6.5 \pm 0.0^{c}$ & $6.6 \pm 0.2^{c}$ & $17.8 \pm 0.2^{b}$ & $7.5 \pm 1.7^{c}$ & $\mathrm{~N}$ \\
\hline CALM & $86.27 \pm 4.67^{c}$ & $14.08 \pm 0.20^{b}$ & $12.5 \pm 0.32^{b}$ & $9.6 \pm 1.0^{b c}$ & $7.3 \pm 0.5^{\mathrm{bc}}$ & $19.8 \pm 0.2^{a b}$ & $8.1 \pm 1.1^{b c}$ & $\mathrm{~N}$ \\
\hline
\end{tabular}

$\mathrm{Sa}=\mathrm{S}$. aureus, $\mathrm{Ec}=E$. coli, $\mathrm{Pa}=P$. aeruginosa, $\mathrm{Bs}=B$. subtilis, $\mathrm{Ca}=C$. albicans, Data are mean $\pm \mathrm{standard}$ deviation, $\mathrm{n}=3 ; \mathrm{N}=\mathrm{no}$ activity.

\section{CONCLUSION}

Lamiaceae plants extracts were found to be rich in phenolic contents therefore; it can be used as free radical scavengers. However qualitative and quantitative analysis of major individual phenolic may explain the relationships between total antioxidant capacity and total phenolic contents in the species. Furthermore, the results indicate that these Lamiaceae leaves extracts can be used as antioxidant and antimicrobial agent without having the toxic effect.

\section{ACKNOWLEDGEMENTS}

This study was supported by Research Management Centre, International Islamic University Malaysia (IIUM) Grant number IIUM/504/Res/G/14//03/05/01/EDW B0803-107. The author would like to thankfully acknowledge the Research Management Centre, International Islamic University Malaysia (IIUM) Kuala Lumpur 5072Malaysia, for the research grant.

\section{REFERENCES}

[1] WHO. WHO Traditional Medicine Strategy. World Health Organization, Geneva (2005). http://whqlibdoc.who.int/hq/ 2002/who_edm_trm_2002.1.pdf

[2] Gordana SĆ, Čanadanović-Brunet MJ, Djilas SM, Tumbas VT, Markov SL. Antioxidant Potential, Lipid Peroxidation Inhibition and Antimicrobial Activities of Satureja montana L. subsp. kitaibelii Extract. Intl J Mol Sci 2007; 8(10): 1013-27. http://dx.doi.org/10.3390/i8101013

[3] Demiray S, Pintado ME, Castro PML. Evaluation of phenolic profiles and antioxidant activities of Turkish medicinal plant: Tilia argentea leaves and Polygonum bistortaroots. World Acad Sci Eng Technol 2009; 54. www.waset.org/journals/ waset/v54/v54-55.pdf

[4] Karou D, Dicko MH, Simpore J, Traore AS. Antioxidant and antibacterial activities of polyphenol from ethnomedicinal plants of Burkina Faso. Afr J Biotech 2005; 4(8): 823-28. www.ajol.info/index.php/ajb/article/viewFile/15190/59507
[5] Muktar H, Katiyar S, Agarwal R. Green tea and skinanticarcinogenic effects. J Invest Dermatol 1994; 102: 3-7. http://dx.doi.org/10.1111/1523-1747.ep12371720

[6] Stanner SA, Hughes J, Kelly CN, Buttriss J. A review of the epidemiological evidence for the 'antioxidant hypothesis' Public Health Nutr 2004; 7(3): 407-22. http://dx.doi.org/10.1079/PHN2003543

[7] Holford. The Optimum Nutrition Bible. London: Butler \& Tanner Ltd. 1997.

[8] Gazzani G, Papetti A, Daglia M, Berte F, Gregotti C. Protective Activity of Water Soluble Components of Some Common Diet Vegetables on Rat Liver Microsome and the Effect of Thermal Treatment. J Agric Food Chem 1998; 46(10): 4123-27.

\section{http://dx.doi.org/10.1021/j980301g}

[9] Vinson JA, Hao Y, Su X, Zubik L. Phenol Antioxidant Quantity and Quality in Foods: Vegetables. J Agric Food Chem 1998; 46(9): 3630-34. http://dx.doi.org/10.1021/jf9802950

[10] Demeule M, Brossard M, Page M, Gingras D, Beliveau R Matrix metalloproteinase inhibition by green tea catechins. Biochim Biophys Acta-Protein Struct Mol Enzymol 2000; 1478(1): 51-60. www.sciencedirect.com/science/article/pii/ S0167483800000091

[11] Charalampos P, Boziaris IS, Kapsokefalou M, Komaitis M Natural Antioxidant Constituents from Selected Aromatic Plants and Their Antimicrobial Activity Against Selected Pathogenic Microorganisms. Food Technol Biotechnol 2008; 46(2): 151-56. http://hrcak.srce.hr/index.php?show=clanak\& id_clanak_jezik=38461

[12] Sari F, Turkmen N, Polat G, Velioglu YS. Total Polyphenol, Antioxidant and Antibacterial Activities of Black Mate Tea. Food Sci Technol Res 2007; 13(3): 265-69. http://dx.doi.org/10.3136/fstr.13.265

[13] Souri E, Amin G, Farsam H, Barazandeh TM. Screening of antioxidant activity and phenolic content of 24 medicinal plant extract. DARU 2008; 16(2): 83-88. http://journals.tums.ac.ir/ $\mathrm{pdf} / 8391$

[14] Gislene NF, Locatelli J, Freitas PC, Silva GL. Antibacterial activity of plant extracts and phytochemicals on antibioticresistant bacteria. Braz J Microbiol 2000; 31: 247-56. www.scielo.br/pdf/bjm/v31n4/a03v31n4.pdf

[15] Kumar VS, Ahmed SM, Badami S, Anil TM, Banji D. Pharmacology online 2008; 3: 224.

[16] Brand-Williams W, Cuvelier ME, Berset C. Antioxidant activity. Food Sci Technol 1995; 28: 25-27. http://www. medlabs.com/Downloads/Antiox_acti_.pdf 
[17] Kronvall KG, Ringertz S, Karlsson I, Göransson E. Laboratory- and species-specific interpretive breakpoints for disk diffusion tests of chloramphenicol susceptibility of Haemophilus influenzae. Antimicrob Agents Chemother 1988; 32: 1484-89.

http://dx.doi.org/10.1128/AAC.32.10.1484

[18] Klančnik A, Piskernik S, Jeršek B, Možina SS. Evaluation of diffusion and dilution methods to determine the antibacterial activity of plant extracts. J Microbiol Methods 2010; 81(2): 121-26.

http://dx.doi.org/10.1016/j.mimet.2010.02.004

[19] Nagshetty K, Channappa ST, Gaddad SM. Antimicrobial susceptibility of Salmonella Typhi in India. J Infect Dev Ctries 2010; 4(2): 70-73. http://www.ncbi.nlm.nih.gov/pubmed/ 20212336

[20] Mothana RA, Lindequist U. Antimicrobial activity of some medicinal plants of the island Soqotra. J Ethnopharmacol 2005; 96(1): 177-81.

http://dx.doi.org/10.1016/j.jep.2004.09.006

[21] Singleton VL, Rossi JA. Colorunetry of total phenolics with phosphomolybdic-phosphotungstic acid reagent. Am J Enology Viticult 1965; 16: 144-58. http://garfield.library. upenn.edu/classics1985/A1985AUG6900001.pdf

[22] Damanik $\mathrm{R}$, Wahlqvist $\mathrm{ML}$, Wattanapenpaiboon $\mathrm{N}$. Lactagogue effects of Torbangun, a Bataknese traditional cuisine. Asia Pac J Clin Nutr 2006; 15(2): 267-74. http://www.ncbi.nlm.nih.gov/pubmed/16672214
[23] Damanik R. Torbangun (Coleus amboinicus Lour): a Bataknese Traditioal Cuisine Perceived as Lactagogue by Bataknese Lactating Women in Simalungun, North Sumatera, Indonesia. J Hum Lact 2009; 25(1): 64-72. http://dx.doi.org/10.1177/0890334408326086

[24] Damanik R, Watanapenpaiboon N, Wahlqvist ML. The Use of a Putative Lactagogue Plant on Breast Milk Production in Simalungun, North Sumatra, Indonesia. Asia Pac J Clin Nutr 2004; 16(4): S87. http://connection.ebscohost.com/c/articles/ 34013603/

[25] Damanik R, Damanik N, Daulay Z, Saragih S, Premier R Wattanapenpaiboon N, Wahlqvist ML. Consumption of Bangun-Bangun Leaves (Coleus amboinicus Lour) to Increase Breast Milk Production among Bataknese Women in North Sumatera Island, Indonesia. Asia Pac J Clin Nutr 2001; 10(4): S67. http://www.docstoc.com/docs/25052957/

[26] Azman MS, Salihon J, Mashitah MY, Ibrahim A, Damanik R. Effect of Temperature and Time to the Antioxidant activity in Coleus amboinicus Lour. Am J Appl Sci 2010; 7(9): 1195-99. http://dx.doi.org/10.3844/ajassp.2010.1195.1199

[27] Paul C, Vlietinck AJ, Berghe DV, Maesa L. Anti-infective potential of natural products: how to develop a stronger in vitro 'proof-of-concept. J Ethnopharmacol 2006; 106: 290302.

http://dx.doi.org/10.1016/j.jep.2006.04.003 